\title{
Berry anthocyanins reduce proliferation of human colorectal carcinoma cells by inducing caspase-3 activation and p21 upregulation
}

\author{
SIRAJUDHEEN ANWAR, DEBORAH FRATANTONIO, DANIELA FERRARI, \\ ANTONELLA SAIJA, FRANCESCO CIMINO and ANTONIO SPECIALE \\ Department of Drug Sciences and Health Products, University of Messina, I-98168 Messina, Italy
}

Received November 26, 2015; Accepted April 28, 2016

DOI: $10.3892 / \mathrm{mmr} .2016 .5397$

\begin{abstract}
Colorectal cancer is the fourth most common type of cancer worldwide, and adenocarcinoma cells that form the majority of colorectal tumors are markedly resistant to antineoplastic agents. Epidemiological studies have demonstrated that consumption of fruits and vegetables that are rich in polyphenols, is linked to reduced risk of colorectal cancer. In the present study, the effect of a standardized anthocyanin (ACN)-rich extract on proliferation, apoptosis and cell cycle in the Caco-2 human colorectal cancer cell line was evaluated by trypan blue and clonogenic assays and western blot analysis of cleaved caspase-3 and $\mathrm{p} 21^{\mathrm{Waf} / \mathrm{Cif} 1}$. The results of the current study demonstrated that the ACN extract markedly decreased Caco- 2 cell proliferation, induced apoptosis by activating caspase-3 cleavage, and upregulated cyclin-dependent kinase inhibitor 1 (p21 $\left.{ }^{\text {Waf/Cifl }}\right)$ expression in a dose dependent manner. Furthermore, ACN extract was able to produce a dose-dependent increase of intracellular reactive oxygen species (ROS) in Caco-2 cells, together with a light increase of the cell total antioxidant status. In conclusion, the present study demonstrated that a standardized berry anthocyanin rich extract inhibited proliferation of Caco-2 cells by promoting ROS accumulation, inducing caspase-3 activation, and upregulating the expression of $\mathrm{p} 21^{\text {Waf/Cif1 }}$.
\end{abstract}

\section{Introduction}

Colorectal cancer (CRC) is the second leading cause of cancer-associated mortality in North America and Europe and the fourth most common form of cancer worldwide (1). Adenocarcinoma cells, including CRC cells, are markedly resistant to damage induced by antineoplastic agents. Thus, these tumors are difficult to treat and often proliferate rapidly under

Correspondence to: Dr Francesco Cimino, Department of Drug Sciences and Health Products, University of Messina, Viale Annunziata, I-98168 Messina, Italy

E-mail: fcimino@unime.it

Key words: colorectal cancer, apoptosis, anthocyanins, p21, Caco-2 conditions that may adversely affect normal cells. This proliferation is also as a result of the inactivation of tumor suppressor genes, including, mutation of cyclin-dependent kinase inhibitor 1 $\left(\mathrm{p} 21^{\text {Waf/Cif1 }}\right.$ ) to produce gene products that do not bind to cyclin, thus the cyclin-dependent kinase remains active and cell division becomes uncontrolled (2).

Numerous studies are focusing on the health benefits of phytochemicals with regards to CRC [(3); also see references cited therein]. Increased levels of phenolic compounds have been detected in animal intestine following oral administration of supplements, compared with other tissues (4). Recent evidence from epidemiological studies indicates that diets rich in fruits and vegetables are associated with a decreased risk of chronic diseases, including cancer (3). Anthocyanins are water-soluble pigments in fruits and vegetables, responsible for red, blue, and purple coloring. The daily intake of anthocyanins in human populations has been shown to vary widely, with estimates between 10 and $215 \mathrm{mg} /$ day. Previous studies indicate that anthocyanins (ACNs) exhibit marked free radical scavenging and antioxidant activities, which is key in the prevention of mutagenesis and carcinogenesis [(5); also see references cited therein]. Furthermore, two recent case control studies have suggested that foods rich in anthocyanidins may be chemopreventive in white men with esophageal adenocarcinoma (6), and that consumption of isoflavones, anthocyanidins, flavones, and flavonols is associated with lower colorectal cancer risk (7). A previous study by Wang et al (8) indicated that consumption of black raspberry powder (at a level of $60 \mathrm{~g}$ daily), which is rich in anthocyanins, exhibits a marked tumor suppressive activity against colorectal cancer via modulating expression of genes associated with the Wnt signaling pathway, proliferation, apoptosis, and angiogenesis. However, the molecular mechanisms underlying the antiproliferative effects of berry anthocyanins remain to be elucidated.

\section{Materials and methods}

Reagents. All the reagents, unless otherwise specified, were purchased from Sigma-Aldrich (St. Louis, MO, USA).

Cell cultures and treatments. The Caco-2 human colon carcinoma cell line and the NIH/3T3 normal murine fibroblast 
cell line were obtained from the American Type Culture Collection (Manassas, VA, USA). NIH/3T3 was selected as it is a preneoplastic cell line, which demonstrates unlimited, yet inhibitable, growth in vitro, however, the cell line does not form colonies in semisolid media or grow as a tumor in nude mice. In all the experiments, the undifferentiated Caco-2 cells and NIH/3T3 cells were cultured in Dulbecco's modified essential medium (DMEM) supplemented with $10 \%$ fetal bovine serum, $4 \mathrm{mM} \mathrm{L-glutamine,} \mathrm{streptomycin} \mathrm{and} \mathrm{penicillin}$ and incubated at $37^{\circ} \mathrm{C}$ in a humidified atmosphere with $95 \%$ air and $5 \% \mathrm{CO}_{2}$.

Exponentially dividing Caco-2 cells are undifferentiated, and differentiation is initiated at confluency when the cells stop dividing. In the present study, Caco-2 cells were investigated as undifferentiated, thus, they were cultured to $\sim 80 \%$ confluency in $75 \mathrm{~cm}^{2}$ plastic flasks.

The anthocyanin $(\mathrm{ACN})$ rich extract $\left(\right.$ Medox $^{\circledR}$; Biolink Group AS, Sandnes, Norway) used in the present study is a dietary supplement consisting of 17 purified ACNs (all glycosides of cyanidin, peonidin, delphinidin, petunidin, and malvidin) isolated from bilberries (Vaccinium myrtillus) and blackcurrant (Ribes nigrum). The glycosides of cyanidin and delphinidin form $\sim 40-50 \%$ of the total anthocyanins (9). For all the experiments the ACN extract was dissolved in dimethyl sulfoxide (DMSO) and used immediately. The final concentration of DMSO in the culture medium during the different treatments was $<0.1 \%$.

Cell proliferation assay. Caco-2 cell proliferation was measured using the trypan blue dye exclusion assay (10). Cells were plated in 12 -well cell plates (initial density, $1 \times 10^{5}$ cells/well) and, after $24 \mathrm{~h}$, were treated with the ACN extract (range, $50-500 \mu \mathrm{g} / \mathrm{ml}$ ) for 24 or $48 \mathrm{~h}$. All wells were trypsinized with trypsin-EDTA and $20 \mu \mathrm{l}$ of cell suspension was mixed with $20 \mu \mathrm{l}$ trypan blue isotonic solution $(0.4 \% \mathrm{w} / \mathrm{v})$ and loaded into a Bright-Line hemacytometer (Hausser Scientific, Horsham, PA, USA) for live and dead cell counting. Results are reported as the number of counted viable cells.

Clonogenic assay. A clonogenic survival test (or colony formation assay) was conducted on Caco-2 cells by plating $1 \times 10^{5}$ cells/well in 6-well plates. After $24 \mathrm{~h}$, cells were treated for 24 or $48 \mathrm{~h}$ with the ACN extract (range, $25-100 \mu \mathrm{g} / \mathrm{ml}$ ) and control cells were treated with the vehicle alone $(0.1 \%$ DMSO). At the end of the treatment, fresh medium (DMEM) was added, and seven days after seeding, the cell colonies that had formed were stained with crystal violet $(0.5 \% \mathrm{w} / \mathrm{v}$ in $\mathrm{MeOH}: \mathrm{H}_{2} \mathrm{O}$ at ratio 1:1) for $30 \mathrm{~min}$, and counted using ImageJ software (imagej.nih.gov/ij/) (11). The colony-forming efficiency was calculated as a percentage compared with the control cells.

Cytotoxicity assay. The cytotoxic effect of the ACN extract on the Caco-2 cancer cell line and the NIH/3T3 normal cell line was investigated using sulforhodamine $\mathrm{B}$, a dye that binds to cellular proteins, as described by Vichai and Kirtikara (12) with certain modifications. NIH/3T3 and Caco-2 cells were plated in 24-well plates at an initial density of $5 \times 10^{4}$ cells/well and $1 \times 10^{5}$ cells/well, respectively. After $24 \mathrm{~h}$, semi-confluent monolayers were treated with the ACN extract for 24 and $48 \mathrm{~h}$, while control cells were exposed to the vehicle alone $(0.1 \%$ DMSO). Cells were fixed using $10 \%$ trichloroacetic acid for $1 \mathrm{~h}$ at $4^{\circ} \mathrm{C}$ and then washed twice with water and incubated with sulforhodamine B $(0.4 \% \mathrm{w} / \mathrm{v}$ in $1 \%$ acetic acid $)$ for $30 \mathrm{~min}$ at room temperature, followed by four washes with $1 \%$ acetic acid. The bound dye was solubilized in $1 \mathrm{ml}$ of $10 \mathrm{mM}$ Tris base solution and the absorbance was measured at a wavelength of $565 \mathrm{~nm}$ using a Shimadzu UV-1601 spectrophotometer (Shimadzu, Japan). The 50\% lethal concentration $\left(\mathrm{LC}_{50}\right)$, defined as the concentration required to kill $50 \%$ of the treated cells compared with untreated control cells, and 95\% confidence limits were calculated using the Litchfield and Wilcoxon test (13) [software: PHARM/PCS version 4 (MCS Consulting)].

Intracellular total antioxidant activity (TAA). Caco-2 and $\mathrm{NIH} / 3 \mathrm{~T} 3$ cells were plated in 6 -well plates at an initial density of $2 \times 10^{5}$ cells/well and $5 \times 10^{4}$ cells/well, respectively. After 3 days, semi-confluent monolayers were treated with the ACN extract (range, $62.5-250 \mu \mathrm{g} / \mathrm{ml}$ ) for $24 \mathrm{~h}$ while control cells were exposed to the vehicle alone (0.1\% DMSO). Following treatment, cells were lysed in water. TAA in cell lysates was determined by decoloration of the radical cation of 2,2-azinobis-(3-ethylbenzothiazoline-6-sulfonic acid) $\left(\mathrm{ABTS}^{\circ+}\right)$, in terms of absorbance quenching at $740 \mathrm{~nm}$. This method determines the capacity of intracellular antioxidants to quench the $\mathrm{ABTS}^{\circ+}$ radical; antioxidants inhibit the reaction, leading to an absorbance decrease, and the extent of inhibition is proportional to the antioxidant concentration in the sample. Values obtained for each sample were compared with the concentration-response curve of a standard Trolox solution, and expressed as nmoles of Trolox Equivalents/mg of protein (TE nmol/mg of protein) (14). Each analysis was conducted in triplicate.

Intracellular reactive oxygen species (ROS) measurement. Generation of ROS was measured by the oxidation-sensitive fluorescent probe, dichloro-dihydro-fluorescein diacetate (DCFH-DA), according to a modified method previously described (15).

Caco-2 and NIH/3T3 cells were plated in 6-well plates at an initial density of $2 \times 10^{5}$ cells/well and $5 \times 10^{4}$ cells/well, respectively. After 3 days, semi-confluent monolayers were treated with the ACN extract (range, 62.5-250 $\mu \mathrm{g} / \mathrm{ml}$ ) for $24 \mathrm{~h}$ while control cells were exposed to the vehicle alone (0.1\% DMSO). Cells exposed to $50 \mu \mathrm{M} \mathrm{H}_{2} \mathrm{O}_{2}$ for $1 \mathrm{~h}$ were used as a positive internal control (data not shown). Cells were washed twice with Dulbecco's phosphate-buffered saline (DPBS), and treated with $50 \mu \mathrm{mol} / 1 \mathrm{DCFH}-\mathrm{DA}$ at $37^{\circ} \mathrm{C}$ for $30 \mathrm{~min}$ in the dark. DCFH-DA was then removed, and cells were washed with DPBS to remove excess probe. Cells were collected using a scraper and resuspended in DPBS. Fluorescence was measured using a spectrofluorometer (model RF5301PC; Shimadzu, Japan) at excitation and emission wavelengths of 485 and $525 \mathrm{~nm}$, respectively. The total protein content was evaluated for each sample using the Bradford assay (16), and results are reported as percentage increase in fluorescence intensity/mg protein compared with the NIH/3T3 control (untreated NIH/3T3 cells). Each analysis was performed in triplicate. 
Western blot analysis. Caco-2 cells were plated in 6-well plates at an initial density of $2 \times 10^{5}$ cells/well. After 3 days, semi-confluent monolayers were treated with the ACN extract (range, 62.5-250 $\mu \mathrm{g} / \mathrm{ml}$ ) for $24 \mathrm{~h}$, and concentrations were selected if they resulted in $>15 \%$ cell death. Control cells were exposed to the vehicle alone $(0.1 \%$ DMSO). Cell lysates were prepared in lysis buffer [10 mM Tris/ $\mathrm{HCl}$ (pH 7.4), $150 \mathrm{mM}$ $\mathrm{NaCl}, 1 \%$ Triton $\mathrm{X}-100,5 \mathrm{mM}$ disodium EDTA] containing protease inhibitors $(1 \mu \mathrm{g} / \mathrm{ml}$ leupeptin, $1 \mathrm{mM}$ benzamidine, $2 \mu \mathrm{g} / \mathrm{ml}$ aprotinin and $1 \mathrm{mM}$ dithiothreitol). Cells were sonicated for $30 \mathrm{sec}$, and the cell lysates were stored at $-70^{\circ} \mathrm{C}$ until use. Protein concentration in lysates was determined using the Bradford assay (16). For immunoblot analyses, $40 \mu \mathrm{g}$ of protein lysates/sample were denatured in SDS-PAGE reducing sample buffer and subjected to SDS-PAGE on 16\% acrylamide/bisacrylamide gels. Separated proteins (150 V for $3 \mathrm{~h}$ ) were transferred to a nitrocellulose membrane [Hybond-P polyvinylidene fluoride (PVDF) membrane; GE Healthcare Life Sciences, Chalfont, UK). The membrane was blocked with $5 \%$ (w/v in Tris-buffered saline-Tween 20) non-fat milk overnight at $4^{\circ} \mathrm{C}$ and then probed with specific primary antibodies: Rabbit monoclonal anti-caspase-3 (cat. no. 9665; 1:1,500; Cell Signaling Technology, Inc., Danvers, MA, USA) and rabbit monoclonal anti-p21 Waf1/Cip1 (cat.no.2947; 1:1,000; CellSignaling Technology, Inc.). Subsequently, the membrane was incubated with horseradish peroxidase-conjugated goat anti-rabbit secondary antibody (polyclonal; cat. no. 554021; 1:5,000; BD Pharmingen, San Diego, CA, USA), and visualized with an Amersham enhanced chemiluminescence (ECL) Plus detection system (GE Healthcare Life Sciences). Blots were detected using High Performance chemiluminescence film (Amersham Hyperfilm ${ }^{\mathrm{TM}}$ ECL; GE Healthcare Life Sciences). The equivalent loading of proteins in each well was confirmed by Ponceau $S$ staining and $\beta$-actin control (mouse anti- $\beta$-actin monoclonal antibody; cat. no. sc-47778; 1:700; Santa Cruz Biotechnology, Inc. Santa Cruz, CA, USA).

Statistical analysis. All the experiments were performed in triplicate and repeated three times. Results are expressed as the mean \pm standard deviation from three experiments and statistically analyzed by a one-way or a two-way analysis of variance (ANOVA) test, followed by Tukey's honest significant difference, using the statistical software ezANOVA (www. cabiatl.com/mricro/ezanova/). $\mathrm{P}<0.05$ was considered to indicate a statistically significant difference.

\section{Results}

ACN extract influences Caco-2 cell growth and viability. To investigate the antiproliferative effect of ACNs on cancer cells, undifferentiated Caco-2 cells were treated with ACN extract for 24 and $48 \mathrm{~h}$ at different concentrations (up to $500 \mu \mathrm{g} / \mathrm{ml}$ ). As presented in Fig. 1, when compared with lower concentrations, the ACN extract induced a significant dose-dependent decrease in Caco- 2 proliferation, as indicated by a reduction in the viable cell count, when cells were treated for 24 and $48 \mathrm{~h}$ (all $\mathrm{P}<0.05$ ).

The antiproliferative effect of the ACN extract on Caco-2 was investigated by clonogenic assay. This assay, also referred to as a colony forming assay, determines the ability of a
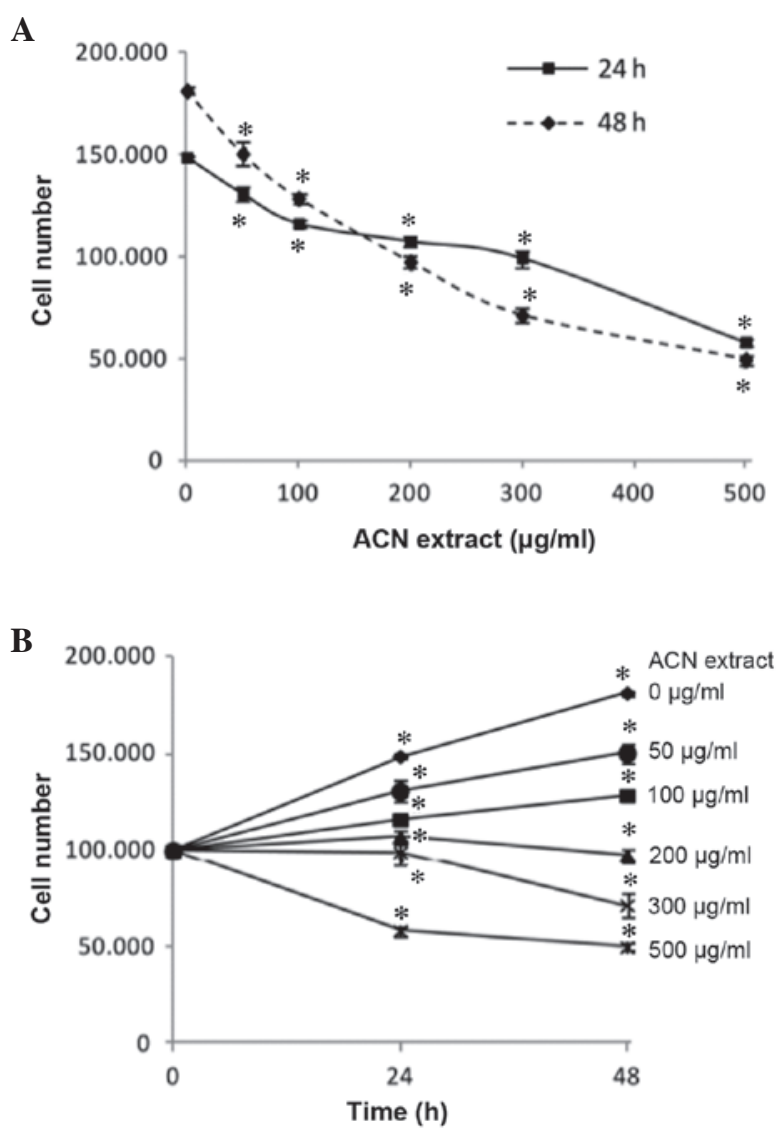

Figure 1. Inhibitory effect of ACN extract on Caco-2 cells growth. (A) Plot of cell number vs. ACN extract concentration; (B) plot of cell number vs time. Exponentially growing Caco-2 cells were treated with the ACN extract $(50-500 \mu \mathrm{g} / \mathrm{ml})$ for 24 and $48 \mathrm{~h}$ and viable cells were counted by trypan blue assay. Cultures treated with the vehicle alone (dimethyl sulfoxide) were used as controls $(0 \mu \mathrm{g} / \mathrm{ml})$. Data are reported as number of counted viable cells. Each point represents the mean \pm standard deviation of three experiments. ${ }^{*} \mathrm{P}<0.05$ vs. all respective lower concentrations. ACN, anthocyanin.

cell to proliferate indefinitely, thereby retaining its reproductive ability to form a large colony. It is widely used to assess the efficacy of novel compounds in anticancer drug discovery programs by determining the effects of cytotoxic and anticancer agents on colony-forming ability (17). For the clonogenic assay, Caco-2 cells were treated for 24 or $48 \mathrm{~h}$ with the ACN extract at increasing doses (range, 25 and $100 \mu \mathrm{g} / \mathrm{ml}$ ) that produce only a weak decrease in cell viability, and the formed cell colonies were counted 7 days after seeding. The ACN extract inhibited the capacity of Caco- 2 to form colonies in a dose-dependent manner, following 24 and $48 \mathrm{~h}$ exposure (all $\mathrm{P}<0.05$; Fig. 2).

In order to characterize the cytotoxic effect of the ACN extract, the viability of NIH/3T3 and Caco- 2 cells exposed for 24 or $48 \mathrm{~h}$ to different concentrations of the ACN extract was investigated. The findings from the present study indicate that the cytotoxic activity of the ACN extract was weaker on normal cells than on cancer cells, suggesting that tumor cells may be a preferential target for its cytocidal effect $(\mathrm{P}<0.05$; Table I).

Effect of ACN extract on intracellular ROS levels and total antioxidant status. The effect of ACN extract treatment 

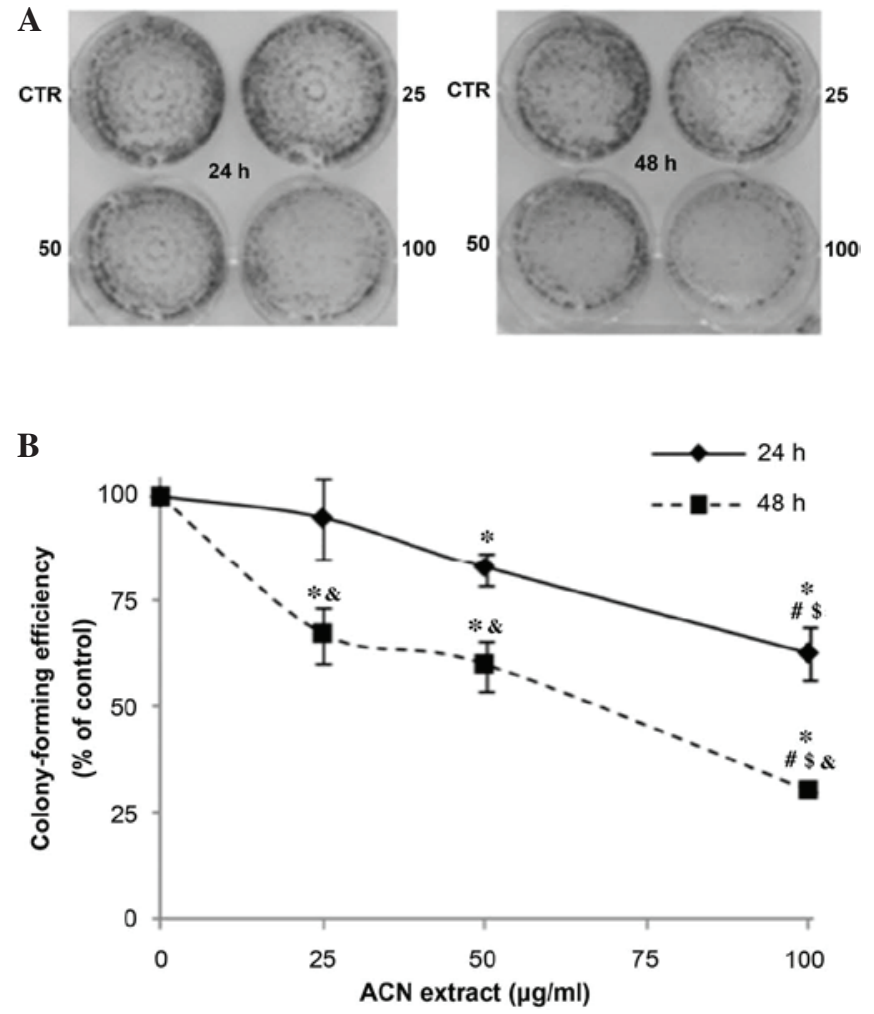

Figure 2. Effect of ACN extract on Caco-2 cells in the clonogenic assay. (A) Representative images of the clonogenic assay; (B) analysis of colony formation rates.Cells were treated for 24 and $48 \mathrm{~h}$ with the ACN extract $(25-100 \mu \mathrm{g} / \mathrm{ml})$ and the number of formed cell colonies was counted 7 days after seeding. Cultures treated with the vehicle alone (dimethyl sulfoxide) were used as controls. Data are expressed as colony-forming efficiency calculated as a percentage with respect to control cells $(0 \mu \mathrm{g} / \mathrm{ml})$. Each point represents the mean \pm standard deviation of three experiments. ${ }^{*} \mathrm{P}<0.05 \mathrm{vs} .0 \mu \mathrm{g} / \mathrm{ml}$ ${ }^{\#} \mathrm{P}<0.05$ vs. $25 \mu \mathrm{g} / \mathrm{ml} ;{ }^{\$} \mathrm{P}<0.05$ vs. $50 \mu \mathrm{g} / \mathrm{ml} ;{ }^{\&} \mathrm{P}<0.05$ vs. respective $24 \mathrm{~h}$ treatment. ACN, anthocyanin; CTR, control.

for $24 \mathrm{~h}$ on intracellular TAA and ROS levels was examined in NIH/3T3 and Caco 2 cells.

TAA was determined in cell lysates according to the capacity to quench the $\mathrm{ABTS}^{\cdot+}$ radical. The ACN extract increased intracellular TAA in a dose-dependent manner in NIH/3T3 and Caco-2 cells, although the effect was more evident in the NIH/3T3 cells. Furthermore, the results suggest there is a difference in the intracellular antioxidant status of the Caco-2 and NIH/3T3 cells. Caco-2 cells exhibit a lower TAA in basal conditions, which is consistent with data supporting persistent oxidative stress in cancer cells (all $\mathrm{P}<0.05$; Table II) $(18,19)$.

ROS levels were measured by DCFH-DA assay, which produces a fluorescence intensity that is proportional to the level of intracellular oxidant species. ACN extract treatment induced a significant and dose-dependent decrease of basal ROS levels in normal NIH/3T3 fibroblasts $(\mathrm{P}<0.05$; Table II). Notably, the same treatment induced instead a dose-dependent increase of ROS levels in Caco-2 cancer cells, which already have a higher basal ROS level compared with NIH/3T3 cells $(\mathrm{P}<0.05$; Table II).

ACN extract induces apoptosis in Caco-2 cells. Caspase-3 is a cytosolic protein that exists as a higher molecular weight inactive precursor (pro-caspase-3). It is proteolytically
Table I. Cytotoxic effect of anthocyanin exposure for 24 or $48 \mathrm{~h}$ evaluated by sulforhodamine B assay.

\begin{tabular}{llc}
\hline & \multicolumn{2}{c}{$\mathrm{LC}_{50}$ and $90 \% \mathrm{CL}(\mu \mathrm{g} / \mathrm{ml})$} \\
\cline { 2 - 3 } Cell line & \multicolumn{1}{c}{$24 \mathrm{~h}$} & \multicolumn{1}{c}{$48 \mathrm{~h}$} \\
\hline NIH/3T3 & $1230(\mathrm{CL} \mathrm{790-1506)}$ & $477^{\mathrm{b}}(\mathrm{CL} \mathrm{364-724)}$ \\
Caco-2 & $494^{\mathrm{a}}(\mathrm{CL} 397-616)$ & $227^{\mathrm{a}, \mathrm{b}}(\mathrm{CL} 186-242)$
\end{tabular}

Control cells were treated with the vehicle (dimethyl sulfoxide) alone. Data are expressed as $\mathrm{LC}_{50}$ and $90 \% \mathrm{CL} .{ }^{\mathrm{a}} \mathrm{P}<0.05$ vs. corresponding $\mathrm{NIH} / 3 \mathrm{~T} 3$ value; ${ }^{\mathrm{b}} \mathrm{P}<0.05$ vs. corresponding $24 \mathrm{~h}$ value. $\mathrm{LC}_{50}, 50 \%$ lethal concentration; CL, confidence limit.

cleaved into a low molecular weight (17 kDa) active enzyme when cells undergo apoptosis (20). To determine whether caspase-3 is involved in this process in Caco-2 cells treated with ACN, a western blot analysis was performed to verifying caspase-3 cleavage status. Results from the present study indicated that the ACN extract induced caspase- 3 activation in a dose-dependent manner after $24 \mathrm{~h}$ of treatment (all $\mathrm{P}<0.05$; Fig. 3).

ACN extract modulates cell cycle-associated proteins in Caco-2 cells. The unlimited replication potential of cancer cells is a result of the inactivation of tumor suppressor genes. $\mathrm{p} 21^{\text {Waf1/Cip1 }}$ is a CDK2 and CDK1 inhibitory protein (21) transcriptionally regulated by $p 53$, which results in $\mathrm{G}_{1}$-phase cell cycle arrest (22). In addition, p21 ${ }^{\text {Waf1/Cip1 }}$ directly inhibits proliferative cell nuclear antigen (PCNA)-dependent DNA replication and modulates the PCNA-dependent DNA repair system (2). Results from the present study indicated that $\mathrm{p} 21^{\mathrm{Waf} 1 / \mathrm{Cip} 1}$ expression was low in undifferentiated Caco- 2 cells, in agreement with data reported by Zhang et al (23). Treatment with the ACN extract (at doses 62.5-250 $\mu \mathrm{g} / \mathrm{ml}$ ) for $24 \mathrm{~h}$ upregulated p21 $1^{\text {Waf1/Cip1 }}$ expression levels in a dose-dependent manner (Fig. 4).

\section{Discussion}

Naturally occurring micronutrients present in the diet are being investigated for their potential as cancer chemopreventive agents. In particular, epidemiological studies have shown that the consumption of fruits and vegetables, rich in polyphenols, is associated with reduced colorectal cancer risk $(24,25)$. Anthocyanins, a widely distributed class of polyphenols, have been reported for their wide variety of biological functions and antioxidant activity, which has been associated with the modulation of carcinogenesis. The intake of anthocyanins, estimated to be between 10 and $215 \mathrm{mg}$ /day depending on the specific dietary profiles of the population, is markedly higher than the $20-25 \mathrm{mg} /$ day range reported for other flavonoids including quercetin and genistein (26). This indicates the intestinal epithelium is exposed to high concentrations of anthocyanins each day.

In the present study, a commercially available extract from bilberries and blackcurrants, rich in anthocyanins, is shown to inhibit the growth of colon cancer cells. Furthermore, the cell 
Table II. Intracellular TAA and ROS in NIH/3T3 and Caco-2 cells after $24 \mathrm{~h}$ exposure to ACN extract $(62.5-250 \mu \mathrm{g} / \mathrm{ml})$.

\begin{tabular}{|c|c|c|c|c|}
\hline \multirow[b]{2}{*}{$\mathrm{ACN}$ extract $(\mu \mathrm{g} / \mathrm{ml})$} & \multicolumn{2}{|c|}{$\begin{array}{c}\text { Intracellular TAA } \\
\text { (TE nmol/mg proteins) }\end{array}$} & \multicolumn{2}{|c|}{$\begin{array}{l}\text { Intracellular ROS } \\
\text { (IF \%/mg proteins) }\end{array}$} \\
\hline & NIH/3T3 & Caco-2 & NIH/3T3 & Caco-2 \\
\hline 0 & $424 \pm 54$ & $228 \pm 3^{\mathrm{d}}$ & 100 & $135 \pm 15^{\mathrm{a}, \mathrm{d}}$ \\
\hline 62.5 & $542 \pm 29^{a}$ & $236 \pm 3^{\mathrm{a}, \mathrm{d}}$ & $66 \pm 2^{a}$ & $235 \pm 25^{\mathrm{a}, \mathrm{d}}$ \\
\hline 125 & $592 \pm 55^{\mathrm{a}}$ & $268 \pm 5^{\mathrm{a}, \mathrm{b}, \mathrm{d}}$ & $46 \pm 13^{\mathrm{a}, \mathrm{b}}$ & $299 \pm 20^{\mathrm{a}, \mathrm{b}, \mathrm{d}}$ \\
\hline 250 & $620 \pm 39^{a, b}$ & $285 \pm 7^{\mathrm{a}-\mathrm{d}}$ & $29 \pm 15^{\mathrm{a}-\mathrm{c}}$ & $310 \pm 25^{\mathrm{a}, \mathrm{b}, \mathrm{d}}$ \\
\hline
\end{tabular}

Cultures treated with the vehicle alone (DMSO $0.1 \%)$ served as controls $(0 \mu \mathrm{g} / \mathrm{ml} \mathrm{ACN})$. TAA data are expressed as nmoles of TE/mg of proteins. Intracellular ROS data are expressed as percentage increase in IF/mg of proteins with respect to NIH/3T3 control (NIH/3T3 cells untreated with the ACN extract). Data are presented as the mean \pm standard deviation of the three independent experiments. ${ }^{a} \mathrm{P}<0.05 \mathrm{vs}$. respective control; ${ }^{b} \mathrm{P}<0.05$ vs. respective $62.5 \mu \mathrm{g} / \mathrm{ml}$; ${ }^{c} \mathrm{P}<0.05$ vs. respective $125 \mu \mathrm{g} / \mathrm{ml}$; ${ }^{\mathrm{d}} \mathrm{P}<0.05 \mathrm{vs}$. respective NIH/3T3 treatment. TAA, total antioxidant activity; ROS, reactive oxygen species; ACN, anthocyanin; TE, Trolox Equivalents; IF, intensity of fluorescence.

A

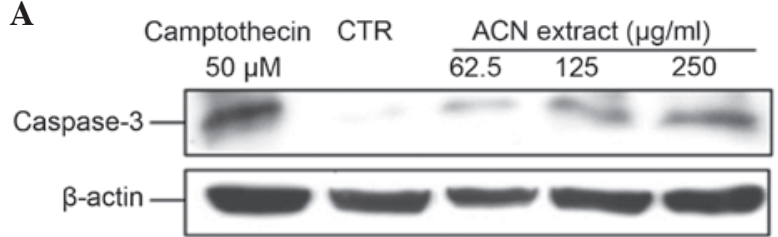

B

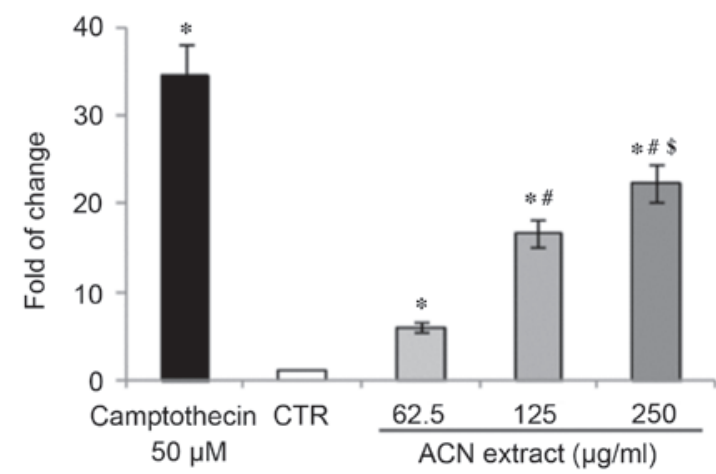

Figure 3. Effect of ACN extract on caspase-3 activation in Caco-2 cells. Cells were treated for $24 \mathrm{~h}$ with different concentrations of the ACN extract, with the vehicle alone (CTR), or with $50 \mu \mathrm{M}$ camptothecin (as positive control). (A) Representative image from three independent experiments; (B) relative quantification of protein product performed by densitometric scanning. Caspase-3 band intensity values were normalized to the corresponding $\beta$-actin value. Data are reported as fold of change vs. control and expressed as the mean \pm standard deviation of three independent experiments. ${ }^{*} \mathrm{P}<0.05$ vs. CTR; ${ }^{*} \mathrm{P}<0.05$ vs. $62.5 \mu \mathrm{g} / \mathrm{ml} ;{ }^{\$} \mathrm{P}<0.05$ vs. $125 \mu \mathrm{g} / \mathrm{ml} . \mathrm{ACN}$, anthocyanin; CTR, control.

growth inhibition of anthocyanins in malignant cells may be due to induction of ROS accumulation in these cells, which interfere with basic cellular functions, including cell cycle progression and apoptosis.

The results of the present study demonstrated that the ACN extract markedly induced a dose-dependent decrease in Caco- 2 cell proliferation, as evidenced by a reduction in the viable cell count and colony formation when cells were exposed to the ACN extract for 24 and $48 \mathrm{~h}$. The results from the current study are consistent with previous studies regarding the antiproliferative efficacy of berry anthocyanins against primary and metastatic colorectal cancer cell lines (27-32).

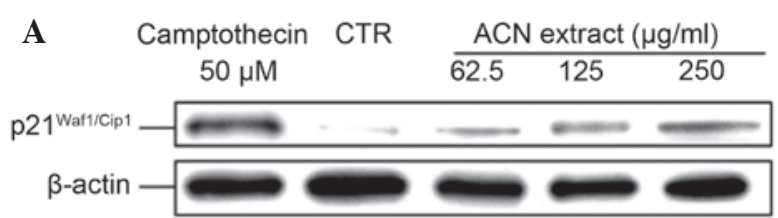

B

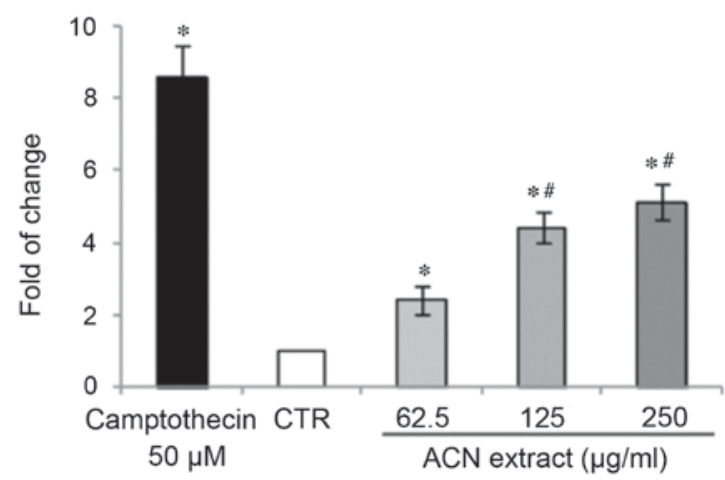

Figure 4. p21 ${ }^{\mathrm{Waf} / \mathrm{Cip} 1}$ protein expression in Caco-2 cells treated for $24 \mathrm{~h}$ with different concentrations of the ACN extract, with the vehicle alone (CTR), or with $50 \mu \mathrm{M}$ camptothecin (as a positive control). (A) Representative image from three independent experiments; (B) relative quantification of protein product performed by densitometric scanning. $\mathrm{p} 21$ band intensity values were normalized to the corresponding $\beta$-actin value. Data are reported as fold of change vs. control and expressed as the mean \pm standard deviation of three independent experiments. ${ }^{*} \mathrm{P}<0.05$ vs. CTR; ${ }^{\#} \mathrm{P}<0.05$ vs. $62.5 \mu \mathrm{g} / \mathrm{ml}$. Cyclin-dependent kinase inhibitor 1, p21 ${ }^{\text {Waf } / \text { Cip1 }}$; ACN, anthocyanin; CTR, control.

The effect observed in the present study was evident at low concentrations $(25-50 \mu \mathrm{g} / \mathrm{ml})$, which are easily reachable into the colon tissue.

It is well documented that ROS are involved in multiple signaling cascades associated with various behaviors in cancer cells, including survival, proliferation, angiogenesis, and metastasis. ROS are thus considered oncogenic and may be responsible for the initiation, development, progression, invasion, and metastasis of cancer. ROS may promote cellular proliferation and contribute to cancer development via numerous signaling pathways $(33,34)$. As discussed in the 'persistent oxidative stress in cancer' hypothesis, cancer cells 
generally have an increased inherent ROS level close to the cell death-triggering threshold and, in addition, tumor cells may also have an impaired antioxidant system. Thus, the molecular mechanisms associated with the antiproliferative effects of ACN were investigated, assuming a possible modulation of intracellular redox status and ROS levels. NIH/3T3 cells (a rapid proliferating normal cell line) and undifferentiated Caco- 2 cells were exposed for $24 \mathrm{~h}$ to different concentrations of the ACN extract, and the intracellular ROS levels and total antioxidant power were evaluated. As presented in Table II, intracellular antioxidant power, at a basal level, was lower in Caco-2 cancer cells compared with normal NIH/3T3 fibroblasts, while intracellular ROS levels being higher in Caco-2 cells is in agreement with the above-mentioned 'persistent oxidative stress in cancer cells' hypothesis. In the current study, the treatment with ACN extract for $24 \mathrm{~h}$ ameliorated the intracellular TAA, and the effect was more evident in normal NIH/3T3 cells compared with Caco- 2 cells. Notably, the ACN extract treatment induced ROS accumulation in malignant cells in a dose-dependent manner, and reduced the level of ROS in normal NIH/3T3 cells.

These results indicate that the accumulation of ROS is an underlying mechanism involved in the cytotoxic effect of the ACN extract on colon cancer cells. The results from the present study further support previous studies demonstrating that numerous plant-derived products induce an antiproliferative effect via cellular ROS generation $(34,35)$. Furthermore, Noda et al (36) demonstrated that, in Caco-2 cells, the addition of N-acetyl-cysteine (a well known antioxidant) restored the intracellular redox balance and, correspondingly, cell proliferative activity.

Dietary compounds have been demonstrated to affect molecular events involved in the initiation, promotion, and progression of cancer, thereby inhibiting carcinogenesis. Apoptosis is one of the most important mechanisms for antitumor activity, and cancer cells differ from normal cells due to the unlimited replication potential and the absence of apoptosis. The current study demonstrated that $\mathrm{ACN}$ extract induces apoptosis by activating caspase-3 cleavage in a dose-dependent manner. These results are supported by previous in vitro studies demonstrating that anthocyanins exhibit pro-apoptotic effects in multiple colorectal cancer cell types in vitro via the caspase-dependent signaling pathways (27,29-32).

A major process in cellular transformation is the loss of control over the mammalian cell cycle. $\mathrm{p} 21^{\text {Waf1/Cipl }}$ promotes cell cycle arrest in response to multiple stimuli, it acts as a sensor and an effector of multiple antiproliferative signals. p2 $1^{\text {Waf1/Cip1 }}$ has exhibited additional and fundamental effects in other important signaling pathways, including regulation of transcription, apoptosis, and DNA repair. Targeting this protein kinase using natural products may be a promising approach for development of anti-cancer therapeutic agents (37). In the present study, p $21^{\text {Waf1/Cipl }}$ expression was low in undifferentiated Caco-2 cells, in agreement with data reported by Zhang et al (23). Furthermore, in vivo loss of $\mathrm{p} 21^{\text {Waf1/Cip1 }}$ control represents a major alteration in cancer cells, which is frequently associated with carcinogenesis increase (38). Notably, the treatment with the ACN extract (range, 62.5-250 $\mu \mathrm{g} / \mathrm{ml}$ ) for $24 \mathrm{~h}$ upregulated p $21^{\text {Waf } 1 / \text { Cipl }}$ expression in a dose-dependent manner. Similarly, an ACN extract from chokeberries inhibited HT-29 cell growth via a marked increase in the expression levels of the $\mathrm{p} 21^{\text {Waf1/Cip1 }}$ gene (28).

In conclusion, the present study suggests exposure to an ACN extract may promote apoptosis in colon cancer cells with high quantities of ROS, by further increasing ROS accumulation and modulating expression of tumor suppressor genes. Although the use of nutritional antioxidants for cancer therapy is complex and requires further research prior to clinical use, the results of the present study suggest a possible chemotherapeutic role of berry ACN extract in treatment of colon cancer and aids in elucidation of the complex cellular mechanisms via which dietary molecules, including ACNs, may inhibit the proliferation of cancer cells.

\section{References}

1. Boyle P and Langman JS: ABC of colorectal cancer: Epidemiology. BMJ 321: 805-808, 2000.

2. Waga S, Hannon GJ, Beach D and Stillman B: The p21 inhibitor of cyclin-dependent kinases controls DNA replication by interaction with PCNA. Nature 369: 574-578, 1994

3. Riboli E and Norat T: Epidemiologic evidence of the protective effect of fruit and vegetables on cancer risk. Am J Clin Nutr 78 (3 Suppl): 559S-569S, 2003.

4. Manach C, Scalbert A, Morand C, Rémésy C and Jiménez L: Polyphenols: Food sources and bioavailability. Am J Clin Nutr 79: 727-747, 2004.

5. Domitrovic R: The molecular basis for the pharmacological activity of anthocyans. Curr Med Chem 18: 4454-4469, 2011

6. Bobe G, Peterson JJ, Gridley G, Hyer M, Dwyer JT and Brown LM: Flavonoid consumption and esophageal cancer among black and white men in the United States. Int JCancer 125: 1147-1154, 2009.

7. Rossi M, Negri E, Talamini R, Bosetti C, Parpinel M, Gnagnarella P, Franceschi S, Dal Maso L, Montella M, Giacosa A and La Vecchia C: Flavonoids and colorectal cancer in Italy. Cancer Epidemiol Biomarkers Prev 15: 1555-1558, 2006.

8. Wang LS, Arnold M, Huang YW, Sardo C, Seguin C, Martin E, Huang TH, Riedl K, Schwartz S, Frankel W, et al: Modulation of genetic and epigenetic biomarkers of colorectal cancer in humans by black raspberries: A phase I pilot study. Clin Cancer Res 17: 598-610, 2011.

9. Qin Y, Xia M, Ma J, Hao Y, Liu J, Mou H, Cao L and Ling W: Anthocyanin supplementation improves serum LDL- and HDL-cholesterol concentrations associated with the inhibition of cholesteryl ester transfer protein in dyslipidemic subjects. Am J Clin Nutr 90: 485-492, 2009.

10. Cimino F, Speciale A, Siracusa L, Naccari C, Saija A, Mancari F, Raciti R, Cristani M and Trombetta D: Cytotoxic effects induced in vitro by organic extracts from urban air particulate matter in human leukocytes. Drug Chem Toxicol 37: 32-39, 2014.

11. Schindelin J, Arganda-Carreras I, Frise E, Kaynig V, Longair M, Pietzsch T, Preibisch S, Rueden C, Saalfeld S, Schmid B, et al: Fiji: An open-source platform for biological-image analysis. Nat Methods 9: 676-682, 2012.

12. Vichai V and Kirtikara K: Sulforhodamine B colorimetric assay for cytotoxicity screening. Nat Protoc 1: 1112-1116, 2006.

13. Litchfield JT and Wilcoxon FA: A simplified method of evaluating dose-effect experiments. J. Pharmacol. Exp. Ther. 96: 99-113, 1949.

14. Cimino F, Speciale A, Anwar S, Canali R, Ricciardi E, Virgili F, Trombetta D and Saija A: Anthocyanins protect human endothelial cells from mild hyperoxia damage through modulation of Nrf2 pathway. Genes Nutr 8: 391-399, 2013.

15. Guo R, Li W, Liu B, Li S, Zhang B and Xu Y: Resveratrol protects vascular smooth muscle cells against high glucose-induced oxidative stress and cell proliferation in vitro. Med Sci Monit Basic Res 20: 82-92, 2014.

16. Bradford MM: A rapid and sensitive method for the quantitation of microgram quantities of protein utilizing the principle of protein-dye binding. Anal Biochem 72: 248-254, 1976.

17. Fiebig HH, Maier A and Burger AM: Clonogenic assay with established human tumour xenografts: Correlation of in vitro to in vivo activity as a basis for anticancer drug discovery. Eur J Cancer 40: 802-820, 2004. 
18. Kondo S, Toyokuni S, Iwasa Y, Tanaka T, Onodera H, Hiai H and Imamura M: Persistent oxidative stress in human colorectal carcinoma, but not in adenoma. Free Radic Biol Med 27: 401-410, 1999.

19. Perse M: Oxidative stress in the pathogenesis of colorectal cancer: Cause or consequence? Biomed Res Int 2013: 725710, 2013.

20. Shalini S, Dorstyn L, Dawar S and Kumar S: Old, new and emerging functions of caspases. Cell Death Differ 22: 526-539, 2015.

21. Satyanarayana A, Hilton MB and Kaldis P: p21 inhibits Cdk1 in the absence of Cdk2 to maintain the G1/S phase DNA damage checkpoint. Mol Biol Cell 19: 65-77, 2008.

22. Waldman T, Kinzler KW and Vogelstein B: p21 is necessary for the p53-mediated G1 arrest in human cancer cells. Cancer Res 55: 5187-5190, 1995.

23. Zhang X, Min KW, Wimalasena J and Baek SJ: Cyclin D1 degradation and p21 induction contribute to growth inhibition of colorectal cancer cells induced by epigallocatechin-3-gallate. J Cancer Res Clin Oncol 138: 2051-2060, 2012.

24. Wang ZJ, Ohnaka K, Morita M, Toyomura K, Kono S, Ueki T, Tanaka M, Kakeji Y, Maehara Y, Okamura T, et al: Dietary polyphenols and colorectal cancer risk: The Fukuoka colorectal cancer study. World J Gastroenterol 19: 2683-2690, 2013.

25. Jedrychowski W, Maugeri U, Popiela T, Kulig J, Sochacka-Tatara E, Pac A, Sowa A and Musial A: Case-control study on beneficial effect of regular consumption of apples on colorectal cancer risk in a population with relatively low intake of fruits and vegetables. Eur J Cancer Prev 19: 42-47, 2010.

26. Speciale A, Cimino F, Saija A, Canali R and Virgili F: Bioavailability and molecular activities of anthocyanins as modulators of endothelial function. Genes Nutr 9: 404, 2014

27. Liu J, Zhang W, Jing $\mathrm{H}$ and Popovich DG: Bog bilberry (Vaccinium uliginosum L.) extract reduces cultured Hep-G2, Caco-2, and 3T3-L1 cell viability, affects cell cycle progression, and has variable effects on membrane permeability. J Food Sci 75: H103-H107, 2010
28. Malik M, Zhao C, Schoene N, Guisti MM, Moyer MP and Magnuson BA: Anthocyanin-rich extract from Aronia meloncarpa $\mathrm{E}$ induces a cell cycle block in colon cancer but not normal colonic cells. Nutr Cancer 46: 186-196, 2003.

29. Lazzè MC, Savio M, Pizzala R, Cazzalini O, Perucca P, Scovassi AI, Stivala LA and Bianchi L: Anthocyanins induce cell cycle perturbations and apoptosis in different human cell lines. Carcinogenesis 25: 1427-1433, 2004.

30. Yi W, Fischer J, Krewer G and Akoh CC: Phenolic compounds from blueberries can inhibit colon cancer cell proliferation and induce apoptosis. J Agric Food Chem 53: 7320-7329, 2005.

31. Renis M, Calandra L, Scifo C, Tomasello B, Cardile V, Vanella L, Bei R,LaFauci L and GalvanoF: Response of cell cycle/stress-related protein expression and DNA damage upon treatment of $\mathrm{CaCo} 2$ cells with anthocyanins. Br J Nutr 100: 27-35, 2008.

32. Cvorovic J, Tramer F, Granzotto M, Candussio L, Decorti G and Passamonti S: Oxidative stress-based cytotoxicity of delphinidin and cyanidin in colon cancer cells. Arch Biochem Biophys 501: 151-157, 2010.

33. Liou GY and Storz P: Reactive oxygen species in cancer. Free Radic Res 44: 479-496, 2010.

34. Loo G: Redox-sensitive mechanisms of phytochemical-mediated inhibition of cancer cell proliferation (review). J Nutr Biochem 14: 64-73, 2003.

35. Sorrenti V, Vanella L, Acquaviva R, Cardile V, Giofrè S and Di Giacomo C: Cyanidin induces apoptosis and differentiation in prostate cancer cells. Int J Oncol 47: 1303-1310, 2015.

36. Noda T, Iwakiri R, Fujimoto K and Aw TY: Induction of mild intracellular redox imbalance inhibits proliferation of $\mathrm{CaCo}-2$ cells. FASEB J 15: 2131-2139, 2001.

37. Neto CC, Amoroso JW and Liberty AM: Anticancer activities of cranberry phytochemicals: An update. Mol Nutr Food Res 52 (Suppl 1): S18-S27, 2008

38. Abbas T and Dutta A: p21 in cancer: Intricate networks and multiple activities. Nat Rev Cancer 9: 400-414, 2009. 